\title{
IMPLICAÇÕES SOCIOAMBIENTAIS DO PROCESSO DE APROPRIAÇÃO E USO DO RIO PARAÍBA DO MEIO EM VIÇOSA (AL)
}

\author{
Social and environmental implications of the process of appropriation \\ and use of the River Paraíba do meio in Viçosa $(A L)$
}

\author{
Everson de Oliveira Santos \\ Mestrando do Programa de Pós-Graduação em Geografia da Universidade Federal de Alagoas \\ (UFAL) \\ eversonoliveira2007.2@gmail.com \\ Paulo Ricardo Petter Medeiros \\ Professor Associado IV da Universidade Federal de Alagoas (UFAL) \\ paulopetteraulas@hotmail.com \\ Cirlene Jeane Santos e Santos \\ Professor Adjunta I da Universidade Federal de Alagoas \\ cirlene.ufal@gmail.com
}

\begin{abstract}
RESUMO: A sociedade ao longo de sua história tem aperfeiçoado, por meio do trabalho, seus instrumentos e técnicas, usando-os para se relacionar com a natureza e transformá-la. $\mathrm{O}$ artigo traz o processo de apropriação e uso dos recursos naturais no município de Viçosa - AL, destacando o rio Paraíba do Meio, evidenciando como a sociedade foi transformando a paisagem. Para identificar tal situação realizaram-se estudos de campo (geológicos, geomorfológicos, etc.) e coletas de amostras nas águas do rio para analisar a qualidade da mesma, mensurando in situ, com a utilização de sonda multiparamétrica YSI 6600, alguns elementos, tais como: oxigênio dissolvido $(\mathrm{mg} / \mathrm{l})$, clorofila a $(\mu \mathrm{g} / \mathrm{l})$ e $\mathrm{pH}$. No decorrer da pesquisa foram verificados desmatamento da mata ciliar, dragagem do leito; bem como, construção de moradias e desenvolvimento de atividades econômicas sem planejamento e controle nas vertentes do rio. Constatou-se que no município de Viçosa - AL, a sociedade ao longo de sua história, no processo de apropriação e uso dos recursos naturais, comprometeu seriamente a área de drenagem do rio, mediante ações carentes de gestão e planejamento, tornando o mesmo, atualmente, impróprio para algumas atividades socioeconômicas.
\end{abstract}

Palavras-chave: Rio Paraíba do Meio. Apropriação e Uso. Problemas Ambientais.

ABSTRACT: Society throughout its history has perfected, through work, its instruments and techniques, using them to relate to nature and to transform it. The article presents the process of appropriation and use of natural resources in the municipality of Viçosa - AL, highlighting the Paraíba do Meio river, showing how society was transforming the landscape. In order to identify this situation, field studies (geological, geomorphological, etc.) were carried out and samples were collected in river waters to analyze the quality of the same, measuring with the use of YSI 6600 multiparameter probe, some elements such as: dissolved oxygen ( $\mathrm{mg} / \mathrm{I})$, chlorophyll a $(\mu \mathrm{g} / \mathrm{I})$ and $\mathrm{pH}$. In the course of the research were verified deforestation of the riparian forest, dredging of the bed; as well as construction of housing and development of economic activities without planning and control in the slopes of the river. It was found that in the municipality of Viçosa - AL, the company throughout its history, in the process of appropriation and use of natural resources, seriously compromised the drainage area of the river, through actions lacking management and planning, currently, unfit for some socioeconomic activities.

Keywords: River Paraíba do Meio; Ownership and Use; Environmental Problems. 
IMPLICAÇÕES SOCIOAMBIENTAIS DO PROCESSO DE APROPRIAÇÃO E USO DO RIO PARAÍBA DO MEIO EM VIÇOSA (AL)

\section{没}

\section{INTRODUÇÃO}

O presente artigo traz uma importante reflexão teórica e de prática acerca da relação do homem com os recursos naturais e suas respectivas implicações socioambientais, isto é, a degradação gerada como resultado desta relação histórica. Evidencia os instrumentos necessários a sociedade para o seu desenvolvimento e em contraponto aponta a problemática que envolve a falta de responsabilidade e consciência ambiental.

Para Marx (apud CASSETI, 1991, p. 53) "a natureza separada da sociedade não possui significado. A natureza sempre é relacionada material e idealmente com a atividade social". Segundo Mendonça Filho (1977, p. 74) "a partir do momento em que surge, o homem passa a produzir, isto é, extrair da natureza, pelo trabalho, os bens de que necessita para satisfazer suas necessidades".

\section{Casseti frisa que}

É através da transformação da primeira natureza em segunda natureza que o homem produz os recursos indispensáveis a sua existência, momento em que se naturaliza (a naturalização da sociedade) incorporando em seu dia-a-dia os recursos da natureza, ao mesmo tempo em que socializa a natureza (modificação das condições originais ou primitivas). (CASSETI, 1991, p. 64)

Ao longo do tempo, no processo de apropriação e uso dos recursos naturais, a sociedade foi transformando a paisagem. Segundo Santos (2004, p. 24) "a paisagem, assim como o espaço, altera-se continuamente para poder acompanhar as transformações da sociedade. A forma é alterada, renovada, suprimida para dar lugar à outra forma que atenda às necessidades novas da estrutura social". Ele continua corroborando que

A paisagem nada tem de fixo, de imóvel. Cada vez que a sociedade passa por um processo de mudança, a economia, as relações sociais e políticas também mudam, em ritmos e intensidades variados. A mesma coisa acontece em relação ao espaço e à paisagem que se transforma para se adaptar às novas necessidades da sociedade. (SANTOS, 2004, p. 25)

Neste sentido, se buscou evidenciar a realidade da relação da sociedade de Viçosa Alagoas com o rio Paraíba do Meio. Desde o início da expansão urbana, variados problemas ambientais foram gerados e, por conseguinte, intensificados no decorrer da ocupação do território. Tal degradação perpassa pelo desmatamento da mata ciliar, ocupação irregular (com a construção de moradias e estabelecimentos comerciais; e a prática de agricultura e pecuária, etc.) na planície de inundação, poluição, contaminação, assoreamento e sua consequente dragagem sem supervisão técnica e fiscalização por parte das autoridades competentes.

Assim, o objetivo da presente pesquisa é compreender não apenas como se dá a relação histórica e necessária entre a sociedade viçosense e o rio Paraíba do Meio, mas, sobretudo os resultados dessa relação. Daí, no conjunto de resultados emanados dessa relação, buscou-se identificar aqueles que, por sua vez, tem

REVISTA GEONORTE, V.9, N.32, p.45-66, 2018.

DOI: 10.21170/geonorte.2018.V.9.N.32.45.66

(ISSN 2237 - 1419) 
provocado o processo de degradação ambiental. Desse modo, a questão da qualidade da água é o tema central aqui discutido, tendo como problemas ambientais associados à questão do desmatamento da mata ciliar, ocupação irregular, dragagem não planejada, assoreamento, dentre outros, como já dito anteriormente.

Para alcançar os objetivos desse estudo realizou pesquisas de campo com entrevistas; coletas de água para análise em laboratório; caracterização física do município; identificação das atividades socioeconômicas e suas relações com o rio e suas implicações ambientais.

O uso da bacia hidrográfica, como unidade natural, possibilita uma visão sistêmica e integrada de todas as características físicas, ambientais e sociais, devido à sua clara delimitação e a natural inter-relação entre os processos ecossistêmicos e atividades antropogênicas. (AB'SÁBER, 2002 apud SPANGHERO, MOREAU e MACEDO, 2017, p. 34)

O presente estudo possibilitou a medição de variados parâmetros importantes para compreender cientificamente o problema ambiental provocado pelo homem na realidade em questão, como por exemplo, Temperatura $\left({ }^{\circ} \mathrm{C}\right)$, Condutividade Elétrica (ms), Nitrato (mg/L), Oxigênio Saturado (\%), Nitrogênio (Amônia) (mg/L), Oxigênio Dissolvido (mg/L), dentre outros. Tais parâmetros estão especificados na resolução do Conselho Nacional de Meio Ambiente - CONAMA, no 357, de 17 de março de 2005. Esta resolução aborda uma discussão em torno desses parâmetros indicando valores que servem como base de referência comparativa.

Portanto, este estudo possibilita compreender de maneira prática e objetiva a degradação ambiental provocada pela relação da sociedade de Viçosa com o rio Paraíba do Meio. Destaca-se que há uma escassez de pesquisas que possam contribuir neste sentido para uma reflexão e formação de consciência ambiental no recorte sociedade $\mathrm{x}$ rio Paraíba do Meio em Alagoas - acrescentando que serve de base para ótica dos outros municípios alagoanos, pois tal problemática se repete. Outra contribuição diferencial desta pesquisa é que a mesma consegue alinhar geograficamente os aspectos físicos e humanos, pois não dicotomiza a Geografia.

\section{CARACTERIZAÇÃO DA ÁREA DE ESTUDO}

O rio Paraíba do Meio nasce na Serra do Gigante em Bom Conselho - PE. Sua bacia abrange os territórios estaduais de Pernambuco (região agreste) e Alagoas (região agreste e zona da mata), sendo assim constituída uma bacia de cunho federal. Sua área totaliza em 3145,2 $\mathrm{km}^{2}$, desta, $1936 \mathrm{~km}^{2}(62,4 \%)$ fazem parte do território alagoano, logo, $1182,2 \mathrm{~km}^{2}(37,6 \%)$ fazem parte do território pernambucano. Apenas o Alto Paraíba localiza-se no estado de Pernambuco, o Médio e Baixo Paraíba estão no Estado de Alagoas. Na figura 1 pode ser observada a localização e abrangência territorial da bacia hidrográfica do rio Paraíba do Meio nos estados de Alagoas e Pernambuco. 


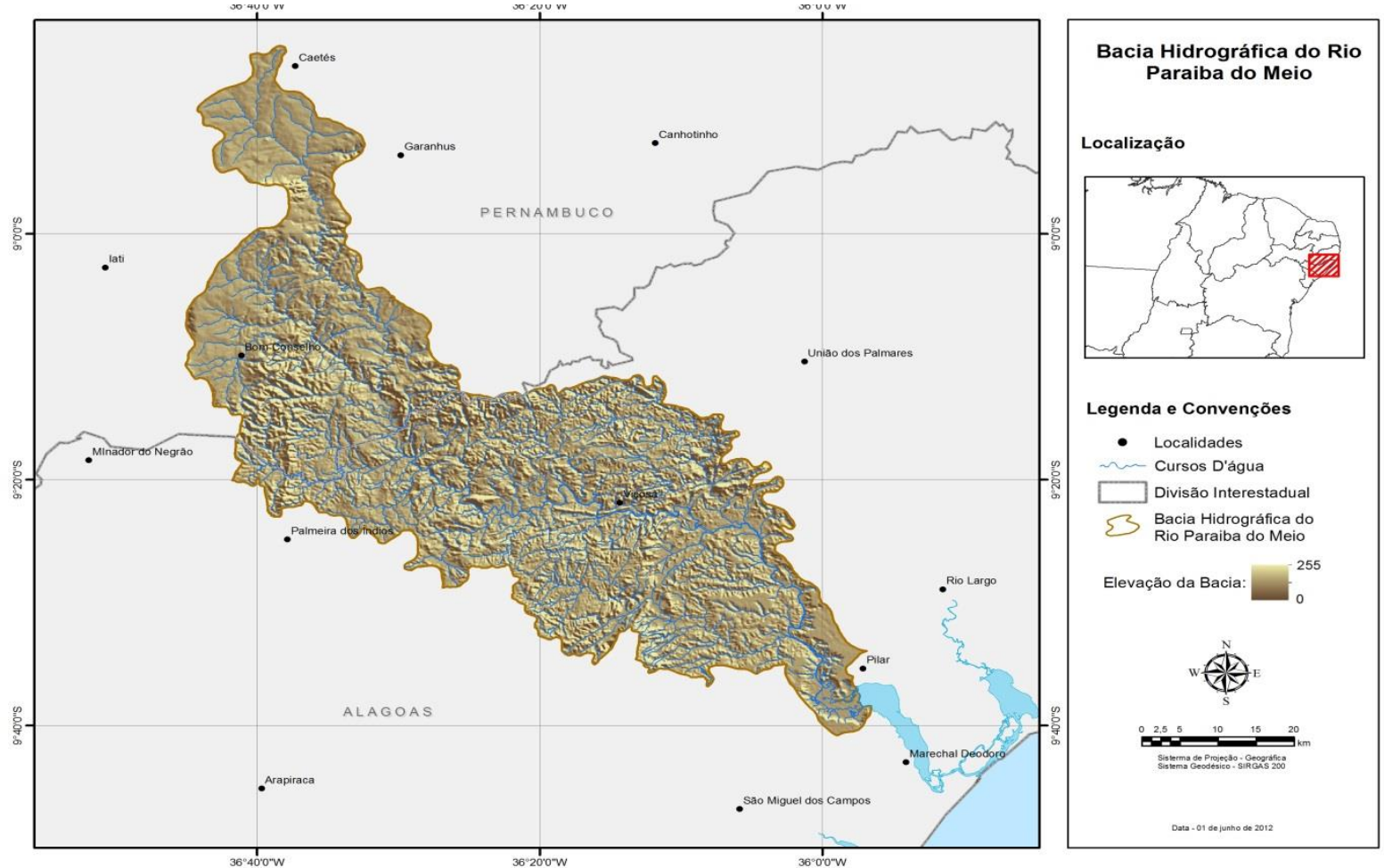

Figura 1: Mapa da localização geográfica da bacia do Rio Paraíba do Meio.

Fonte: LGA/IGDEMA/UFAL, 2012.

Em Alagoas é considerado o terceiro maior rio em extensão, ficando atrás somente do rio São Francisco e Mundaú. Logo, em Alagoas tem-se um total de 13 municípios, a saber, Atalaia, Cajueiro, Capela, Chã Preta, Marechal Deodoro, Maribondo, Mar Vermelho, Palmeira dos Índios, Paulo Jacinto, Pilar (o rio deságua a aproximadamente $2 \mathrm{~km}$ ao sul de sua sede, na laguna Manguaba), Pindoba, Quebrangulo e Viçosa. Em Pernambuco ele drena em 8 municípios: Bom Conselho, Brejão, Terezinha, Paranatama, Caetés, Garanhuns, Saloá e Lagoa do Ouro.

Os afluentes principais da bacia hidrográfica do rio Paraíba do Meio em Alagoas são, a saber: na vertente direita têm-se o Bálsamo, Quebrangulo, Riachão, Itapecuru, Branca e Porangaba. Na vertente esquerda têm-se Carangueja, Riachão de Cima, Taquara, Casaco, Anelsinho, Caçamba, Recanto, Paraibinha e Cacimbinhas. No município de Viçosa os afluentes são: Bálsamo, Porangaba e Riachão, Limoeiro, Paraibinha, Riacho do Meio e Gurungumba.

Desse modo, o presente estudo não abrange a bacia como um todo em Alagoas, pois o mesmo delimita-se a área de drenagem do rio no meio urbano da cidade de Viçosa - Alagoas. Na figura 2 observa-se a localização geográfica do município supracitado, bem como a área urbana do município e a drenagem do rio pelo meio da cidade. 


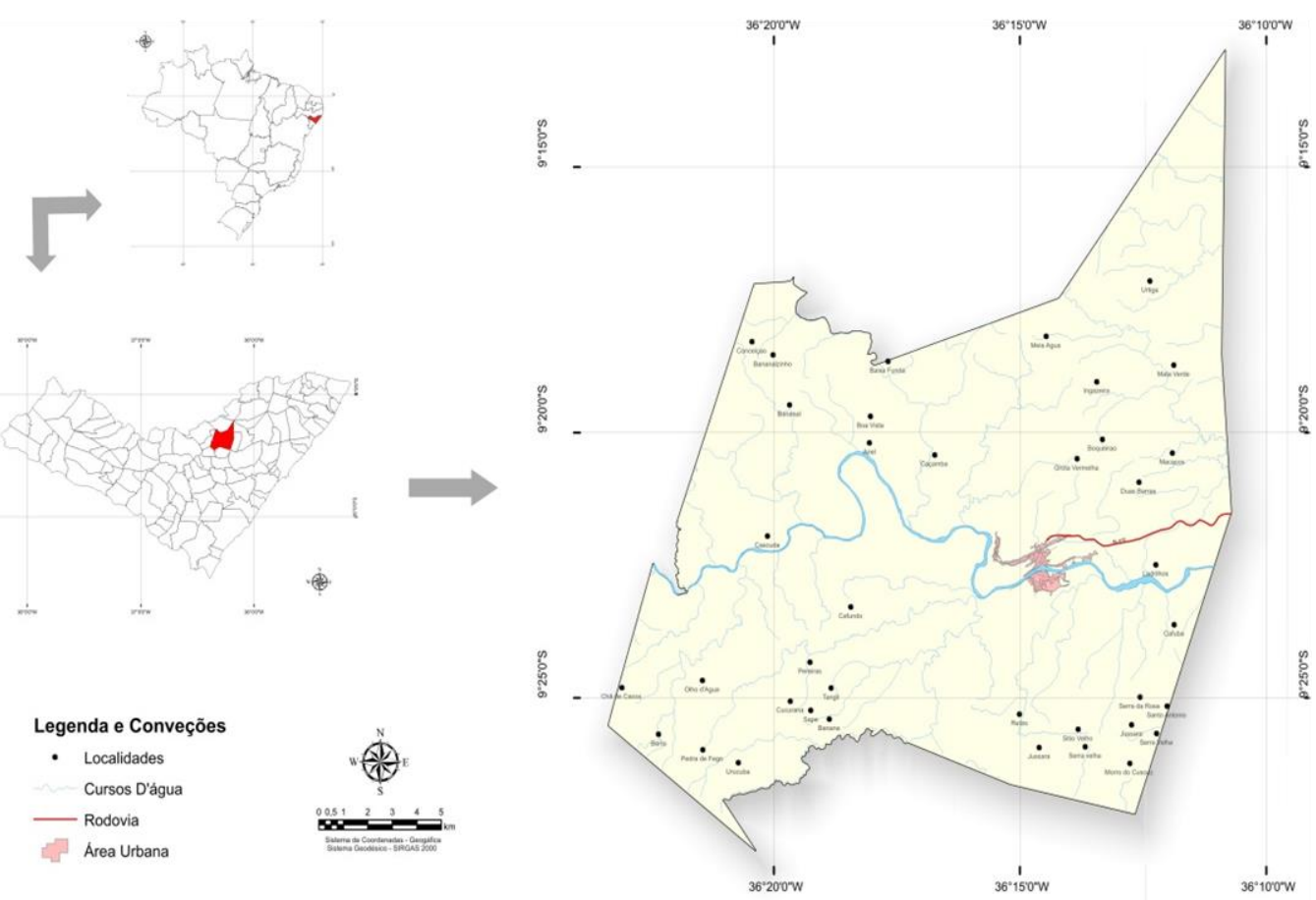

Figura 2: Mapa de localização do município de Viçosa-Alagoas e área de drenagem urbana. Fonte: LGA/IGDEMA/UFAL, 2012.

De acordo com o estudo realizado em 2005 pelo Serviço Geológico do Brasil (CPRM) em parceria com o Ministério de Minas e Energia e a Secretaria de Geologia, Mineração e Transformação Mineral, a geomorfologia de Viçosa é caracterizada pela predominância (cerca de $60 \%$ ), da unidade de superfícies retrabalhadas, isto é, formada por áreas que tem passado por um intenso retrabalhamento. Desse modo, seu relevo é bastante dissecado e com vales profundos.

Ainda de acordo com a CPRM, no que se refere à unidade geoambiental do Planalto da Borborema, Viçosa possui cerca de $25 \%$ dessa unidade. É caracterizada por ser formada por maciços e outeiros altos, com relevo geralmente movimentado, apresentando vales profundos e estreitos. Os cerca de $15 \%$ da área territorial do município em questão está relacionado a unidade geoambiental da Depressão Sertaneja, caracterizada por uma paisagem típica do semiárido nordestino, com superfícies de pediplanação, nesta o relevo é predominantemente suave-ondulado e cortada por vales estreitos e vertentes dissecadas.

Ainda neste estudo supracitado é apontado que o clima é do tipo Tropical Chuvoso com verão seco. A precipitação média anual é de $1.309,9 \mathrm{~mm}$. A vegetação predominante é do tipo Floresta Subperenifólia, com partes de Floresta Hipoxerófila. O município encontra-se geologicamente inserido na Província Borborema, abrangendo rochas do embasamento gnáissico-migmatítico, datadas do Arqueano ao Paleoproterozóico e a sequência metamórfica oriunda de eventos tectônicos ocorridos durante o Meso e NeoProterozóico.

Os solos são representados pelos Latossolos nos topos planos, sendo profundos e bem drenados; pelos Podzólicos nas vertentes íngremes, sendo pouco a 
medianamente profundos e bem drenados; pelos Gleissolos de Várzeanos fundos de vales estreitos, com solos orgânicos e encharcados.

Inserida na Mesorregião do Leste Alagoano e na Microrregião Serrana dos Quilombos, Viçosa possui uma área territorial de $343,356 \mathrm{~km}^{2}$, tendo como população absoluta, segundo censo do Instituto Brasileiro de Geografia e Estatística (IBGE) em 2010, um total de 25.407 hab., sendo a estimativa para 2017 é de 26.143 hab. É considerada uma cidade polo, por concentrar e oferecer serviços e bens que influenciam cidades adjacentes. A economia baseia-se de forma dominante, na pecuária bovina, primordialmente a de corte, com produção diminuta na pecuária de leite. A principal atividade agrícola continua sendo a cana-de-açúcar; a agricultura tradicional (batata, feijão, milho, fava, etc.) ocorre, contudo é inexpressiva.

\section{MATERIAIS E MÉTODOS}

\section{Periodicidade e metodologia de Coleta}

Com o objetivo de avaliar a variabilidade da qualidade de água do Rio Paraíba do Meio foram realizadas duas campanhas de amostragens, uma em cada semestre do ano de 2011. A primeira campanha foi realizada no dia 11/04/2011 (primeiro semestre), a segunda no dia 09/11/2011 (segundo semestre).

Foram estabelecidos três pontos para coleta: ponto 01, ponto 02 e ponto 03 . As coordenadas geográficas em UTM, respectivamente, são: 803605 E / 8962396 N; 804472 E / 8962652 N; 802677 E / 8962360 N.

As amostras foram coletadas nas águas do rio (em torno de $30 \mathrm{~cm}$ abaixo da linha da água, com garrafa de coleta tipo Van Dorn). O ponto de coleta no 01 refere-se à "Ponte Velha"; ponto de coleta $n^{\circ} 02$ refere-se à "Ponte Nova" e o ponto $n^{\circ} 03$ ao Matadouro Público Municipal de Viçosa (atualmente desativado). Consiste na verdade, em pontos que vislumbram o início, meio e fim do curso de água do rio Paraíba do Meio no adensamento urbano de Viçosa.

Nesta etapa, foram medidos in situ os seguintes parâmetros com a utilização de sonda multiparamétrica YSI 6600: Temperatura $\left({ }^{\circ} \mathrm{C}\right), \mathrm{pH}$, Condutividade Elétrica (ms), STD (mg/L), Nitrato (mg/L), Oxigênio Saturado (\%),Nitrogênio (Amônia) (mg/L), Oxigênio Dissolvido (mg/L), Sal, Nitrito (mg/L), Silício (mg/L), Fósfoto (Orto) ( $\mu \mathrm{g} / \mathrm{L})$, Fósforo Total $(\mathrm{mg} / \mathrm{L})$, Clorofila a $(\mu \mathrm{g} / \mathrm{L})$. A transparência da água foi medida com disco de Secchi.

Os dados das vazões do rio Paraíba do Meio foram obtidos no site da Agência Nacional de Águas (ANA). Foram calculadas médias e desvios históricos, a partir de uma série de dados de 32 anos (1978 a 2010). 
IMPLICAÇÕES SOCIOAMBIENTAIS DO PROCESSO DE APROPRIAÇÃO E USO DO RIO PARAÍBA DO MEIO EM VIÇOŞA (AL)

\section{渷}

\section{Metodologia analítica}

Pauta-se na análise em laboratório, a saber: Laboratórios Integrados de Ciências do Mar e Naturais e Laboratório de Hidroquímica. Nestes foram medidos os seguintes parâmetros: amônia, nitrito, nitrato, fósforo dissolvido, fósforo total, silicato, material em suspensão. Tais parâmetros foram analisados levando em consideração as proposições de Strickland e Parsons (1972), Grasshoff (1983) e Apha (1992). E mais, levou-se em consideração, na análise dos parâmetros, os valores referenciais estabelecidos pelo CONAMA, nํ357, de 17 de março de 2005.

\section{Metodologia de campo (demais tipologias de degradação)}

Para compreensão dos problemas ambientais que estão para além das alterações na qualidade da água realizou-se atividades sistemáticas de observação direta em campo com a construção de relatórios e de um acervo iconográfico e, sobretudo, buscando relacionar os resultados desta observação com o arcabouço teórico da pesquisa. E mais: pesquisas na sede do IBGE no município de Viçosa-AL acerca de dados socioeconômicos; entrevistas em forma de diálogo com moradores da cidade, tendo como público alvo principal pessoas que moram há bastante tempo no município (para poder contribuir para visão holística da pesquisa) e as instituições envolvidas direta e indiretamente em alguma forma de degradação ambiental que afeta rio em análise.

\section{RESULTADO E DISCUSSÕES}

\section{Hidrologia}

O rio Paraíba do Meio, com base em sua variação mensal da vazão histórica (figuras 3,4 e 5), pode ser classificado como um rio de regime fluvial simples. Este apresenta um único período de vazões máximas anuais, correspondente ao mês de maio até o mês de agosto.

Regime fluvial ou hidrográfico, segundo Guerra e Guerra (2010, p. 524), é a "variação do nível das águas de um rio durante o ano", isto é, a forma como o rio é alimentado por água. Os supracitados autores corroboram que o escoamento das águas depende do clima, daí a existência de rios de regime nival ou glaciário e de regime pluvial. Este último tipo caracteriza o rio Paraíba do Meio, pois de acordo com Guerra e Guerra (2010, p. 525), este tipo de regime são os rios que "são alimentados pelas águas das chuvas, coincidindo as grandes cheias com a estação chuvosa".

O ano estudado (2011) apresentou vazão média anual superior à média histórica anual (figura 3), respectivamente $250 \mathrm{~m}^{3} / \mathrm{s}$ e $185 \mathrm{~m}^{3} / \mathrm{s}$. Os meses que foram realizados as amostragens, abril e novembro de 2011 também apresentaram maiores vazões 
quando comparados aos dados históricos (figura 5). O mês de abril apresentou vazão mensal de $276 \mathrm{~m}^{3} / \mathrm{s}$, superior a média histórica de 32 anos, a qual foi $151 \mathrm{~m}^{3} / \mathrm{s}$. O mês de novembro apresentou vazão de $163 \mathrm{~m}^{3} / \mathrm{s}$, também superior a média histórica de $65 \mathrm{~m}^{3} / \mathrm{s}$. As maiores vazões nos meses amostrados, sugerem uma maior capacidade de transporte de materiais e potencial erosivo do rio Paraíba do Meio nesses meses.

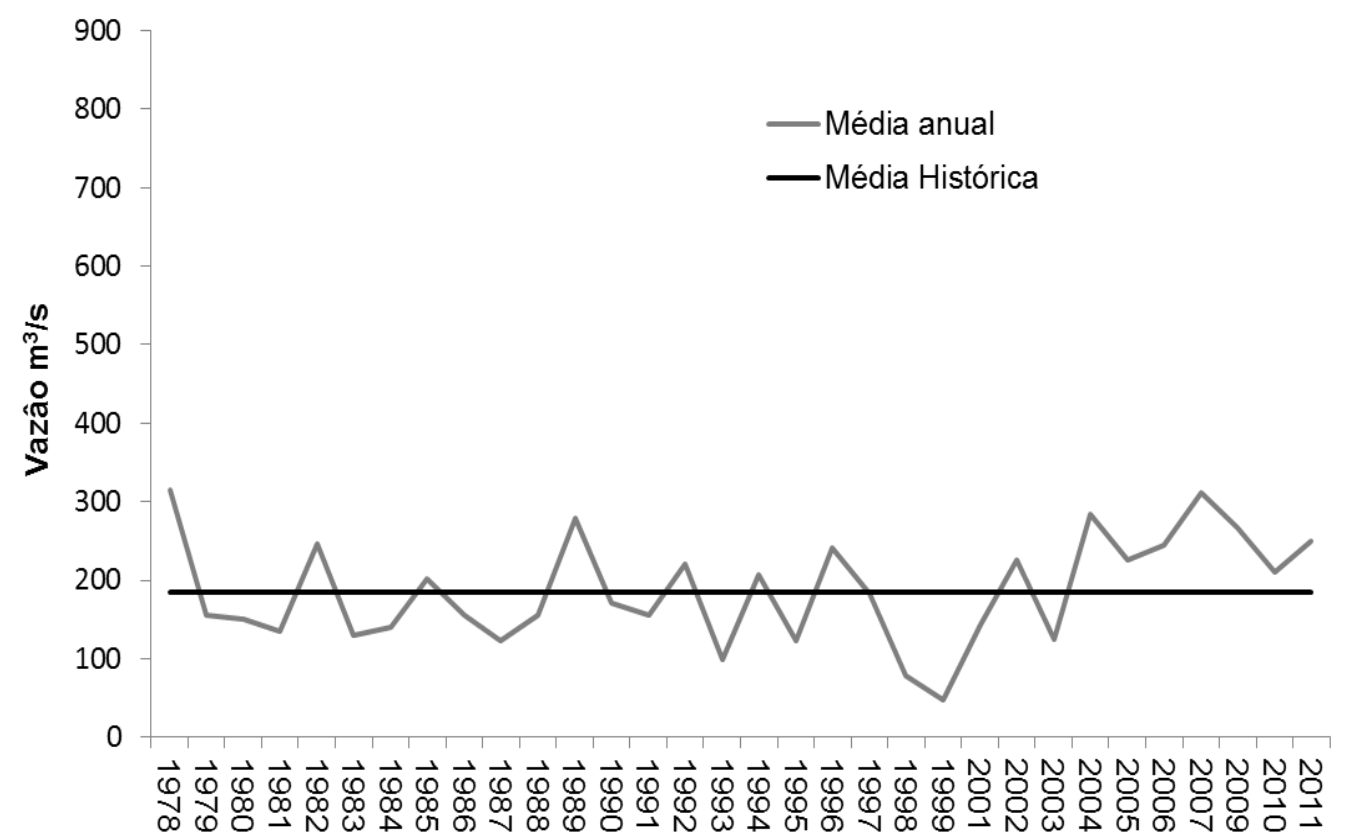

Figura 3: Comportamento da vazão do rio Paraíba do Meio: média anual e média histórica. Fonte: ANA, 2018.

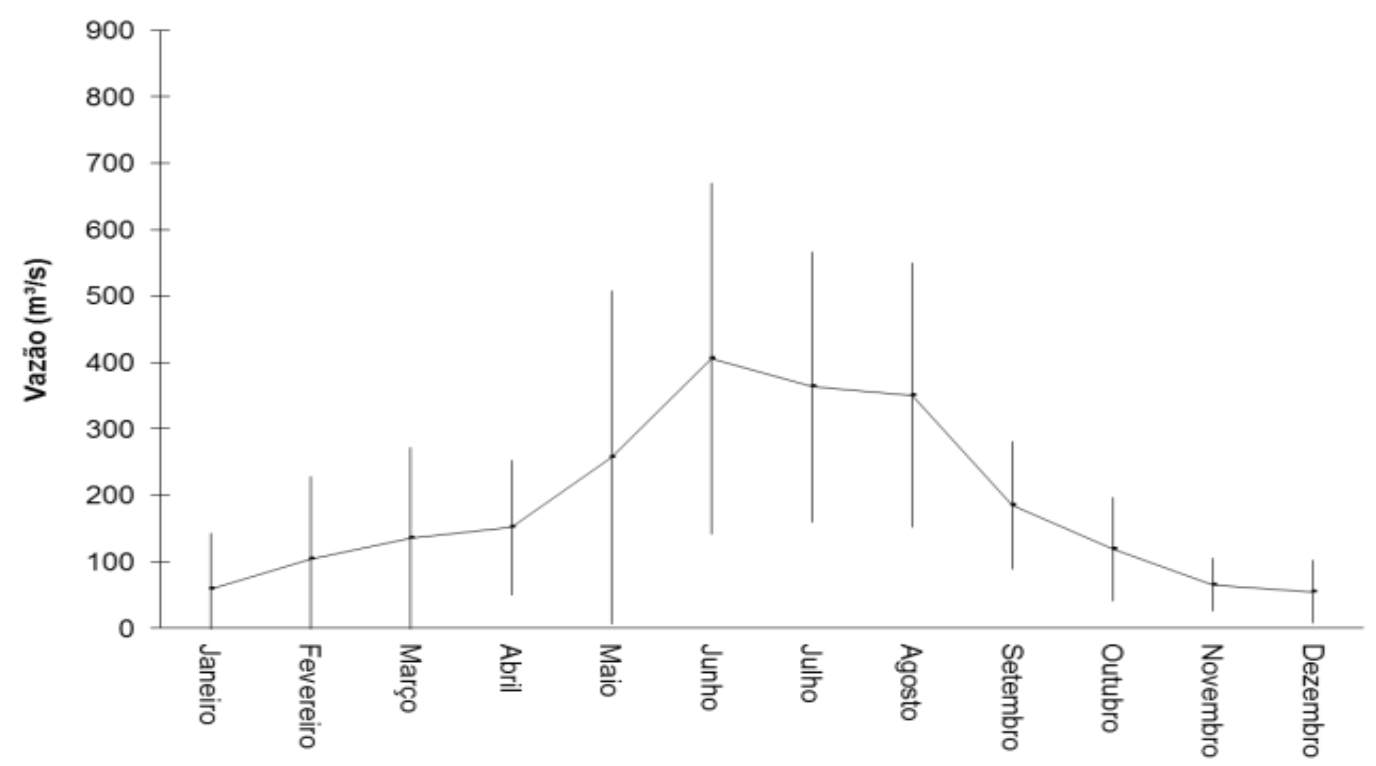

Figura 4: Comportamento da vazão do rio Paraíba do Meio:Média e desvio padrão históricos. Fonte: ANA, 2018. 


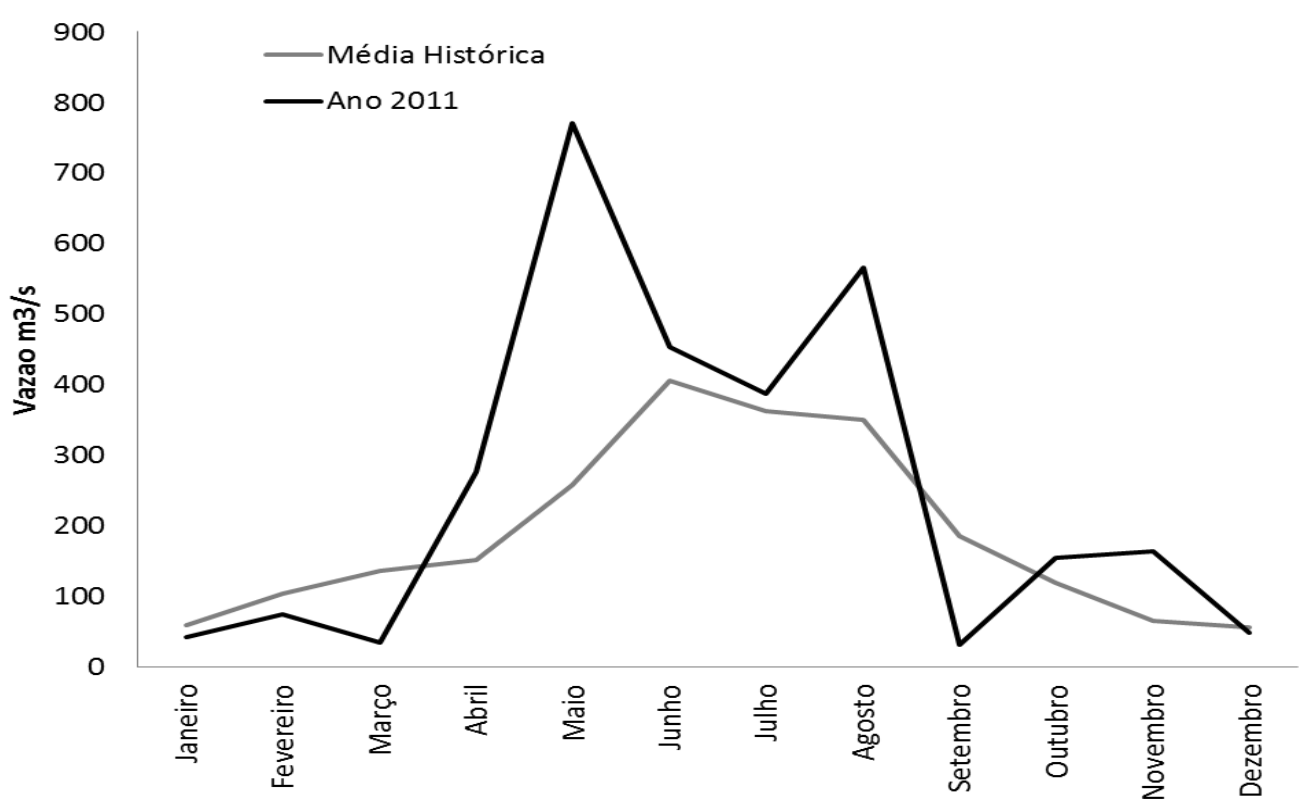

Figura 5: Comportamento da vazão do rio Paraíba do Meio: média do ano de 2011 e média histórica. Fonte: ANA, 2018.

\section{ALTERAÇÕES NA QUALIDADE DA ÁGUA}

Á água é um recurso hídrico fundamental para o desenvolvimento e o crescimento socioeconômico e, sobretudo, para manutenção da vida humana. A ação humana vem de maneira significativa poluindo e contaminando os ecossistemas aquáticos, provocando alterações na qualidade da água. Segundo Braga e colaboradores (2008) citado por Morais e Sais (2016, p. 45) "a água é um recurso natural com múltiplos usos além de ser essencial à vida humana e ao funcionamento dos ecossistemas".

Os espaços aquáticos bem como os recursos hídricos de maneira geral, são utilizados em todo o mundo com distintas finalidades, entre as quais se destacam o abastecimento de água, a geração de energia, a irrigação, a navegação, a aquicultura e a harmonia paisagística. A água representa, sobretudo, o principal constituinte de todos os organismos vivos (MORAES e JORDÃO, 2002 apud MORAIS e SAIS, 2016, p. 62).

As principais causas de impactos ambientais em uma bacia hidrográfica estão relacionadas às interferências antrópicas no meio, tal como o lançamento de efluentes domésticos e industriais, ocupação irregular, supressão vegetal e outras ações antrópicas que venham a modificar a cobertura vegetal, principalmente nas áreas de preservação permanente (APP), ao longo dos cursos d'água. (SPANGHERO, MOREAU e MACEDO, 2017, p. 52)

É neste sentido que se buscou identificar tais alterações, isto é, na realização de coletas de água diretamente do leito do rio para análise em laboratório, conforme descrito na metodologia de coleta e analítica. Abaixo, nas tabelas 1 e 2, tem-se o panorama dos resultados das coletas e seus respectivos parâmetros então trabalhados. 
IMPLICAÇÕES SOCIOAMBIENTAIS DO PROCESSO DE APROPRIAÇÃO E USO DO RIO PARAÍBA DO MEIO EM VIÇOSA (AL)

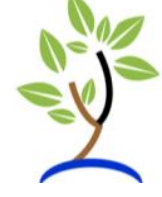

Tabela 1: Parâmetros medidos na coleta do primeiro semestre de 2011.

\begin{tabular}{|l|l|l|l|l|l|l|l|}
\hline & $\begin{array}{l}\text { Temperatura } \\
\left({ }^{\circ} \mathbf{C}\right)\end{array}$ & $\mathbf{p H}$ & $\begin{array}{l}\text { Condutividade } \\
\text { Elétrica }(\square \mathbf{s})\end{array}$ & $\begin{array}{l}\text { STD } \\
(\mathbf{m g} / \mathbf{L})\end{array}$ & $\begin{array}{l}\text { Nitrato } \\
(\mathbf{m g} / \mathbf{L})\end{array}$ & $\begin{array}{l}\text { Oxigênio } \\
\text { Saturado } \\
(\%)\end{array}$ & $\begin{array}{l}\text { Nitrogênio } \\
(\mathbf{A m o ̂ n i a )} \\
(\mathbf{m g} / \mathbf{L})\end{array}$ \\
\hline PONTO 01 & 26 & -- & 450 & 292 & 0,22 & 93 & 0,20 \\
\hline PONTO 02 & 26 & -- & 452 & 293 & 0,20 & 86 & 0,25 \\
\hline PONTO 03 & 26,33 & -- & 455 & 295 & 0,19 & 94,4 & 0,19 \\
\hline & $\begin{array}{l}\text { Oxigênio } \\
\text { Dissolvido } \\
(\mathbf{m g} / \mathbf{L})\end{array}$ & Sal & Nitrito (mg/L) & $\begin{array}{l}\text { Silício } \\
(\mathbf{m g} / \mathbf{L})\end{array}$ & $\begin{array}{l}\text { Fósfoto } \\
(\mathbf{O r t o}) \\
(\boldsymbol{\mu g} / \mathbf{L})\end{array}$ & $\begin{array}{l}\text { Fósforo } \\
\text { Total (mg/L) }\end{array}$ & $\begin{array}{l}\text { Clorofila a } \\
(\boldsymbol{\mu g} / \mathbf{L})\end{array}$ \\
\hline PONTO 01 & 7,53 & 0,21 & 0,05 & 4,87 & 127,07 & 0,27 & -- \\
\hline PONTO 02 & 6,96 & 0,22 & 0,05 & 4,99 & 137,66 & 0,23 & -- \\
\hline PONTO 03 & 7,6 & 0,22 & 0,04 & 4,92 & 120,45 & 0,18 & -- \\
\hline
\end{tabular}

Fonte: Laboratório de Hidroquímica da UFAL/IGDEMA, 2011.

Tabela 2: Parâmetros medidos na coleta do segundo semestre de 2011.

\begin{tabular}{|l|l|l|l|l|l|l|l|}
\hline & $\begin{array}{l}\text { Temperatura } \\
\left({ }^{\circ} \mathbf{C}\right)\end{array}$ & $\mathbf{P h}$ & $\begin{array}{l}\text { Condutividade } \\
\text { Elétrica }(\square \mathbf{s})\end{array}$ & $\begin{array}{l}\text { STD } \\
(\mathbf{m g} / \mathbf{L})\end{array}$ & $\begin{array}{l}\text { Nitrato } \\
(\mathbf{m g} / \mathbf{L})\end{array}$ & $\begin{array}{l}\text { Oxigênio } \\
\text { Saturado } \\
(\%)\end{array}$ & $\begin{array}{l}\text { Nitrogênio } \\
(\mathbf{A m o ̂ n i a}) \\
(\mathbf{m g} / \mathbf{L})\end{array}$ \\
\hline PONTO 01 & 26,67 & 8,17 & 269 & 175 & 0,20 & 64,6 & 0,12 \\
\hline PONTO 02 & 27,58 & 8,14 & 272 & 176 & 0,23 & 76 & 0,06 \\
\hline PONTO 03 & 27,39 & 8,08 & 266 & 173 & 0,23 & 91,6 & 0,04 \\
\hline & $\begin{array}{l}\text { Oxigênio } \\
\text { Dissolvido } \\
(\mathbf{m g} / \mathbf{L})\end{array}$ & Sal & Nitrito $(\mathbf{m g} / \mathbf{L})$ & $\begin{array}{l}\text { Silício } \\
(\mathbf{m g} / \mathbf{L})\end{array}$ & $\begin{array}{l}\text { Fósfoto } \\
(\mathbf{O r t o}) \\
(\boldsymbol{\mu g} / \mathbf{L})\end{array}$ & $\begin{array}{l}\text { Fósforo } \\
\text { Total (mg/L) }\end{array}$ & $\begin{array}{l}\text { Clorofila a } \\
(\mathbf{\mu g} / \mathbf{L})\end{array}$ \\
\hline PONTO 01 & 6,74 & 0,13 & 0,01 & 4,99 & 79,42 & 0,14 & 2,1 \\
\hline PONTO 02 & 7 & 0,13 & 0,01 & 6,22 & 76,77 & 0,14 & 1,5 \\
\hline PONTO 03 & 7,2 & 0,12 & 0,01 & 5,27 & 79,42 & 0,13 & 2,3 \\
\hline
\end{tabular}

Fonte: Laboratório de Hidroquímica da UFAL/IGDEMA, 2011.

As atividades agrícolas justificam um dos resultados das coletas: o Ortofosfato, estes têm como ponto crucial de origem os fertilizantes fosfatados que são utilizados em atividades agrícolas. Além de ser considerado um elemento primordial e indicativo de estado de eutrofização de ecossistemas aquáticos, geralmente, em corpos de água continental, ele é um fator limitante para a produtividade dos mesmos. E mais, dentre as formas ou frações de fosfato a que possui maior relevância do ponto de vista hidrológico é o Fósforo (Orto), pois é a principal forma de fosfato assimilada pelos vegetais.

Há muito é conhecida a importância do fósforo nos sistemas biológicos. Esta importância deve-se à participação deste elemento em processos fundamentais do metabolismo dos seres vivos, tais como: armazenamento de energia (forma uma fração essencial da molécula de ATP) e estruturação da membrana celular (através dos fosfolipídios). (ESTEVES, 1998, p. 53)

De acordo com os parâmetros analisados em laboratório, durante o segundo semestre tem-se uma variação da concentração de ortofosfatos de $76,77 \mu \mathrm{g} / \mathrm{L}$ a $79,42 \mu \mathrm{g} / \mathrm{L}$. No primeiro semestre a variação que se efetiva está relacionada a concentrações

REVISTA GEONORTE, V.9, N.32, p.45-66, 2018.

(ISSN 2237 - 1419)

DOI: $10.21170 /$ geonorte.2018.V.9.N.32.45.66 
maiores, pois fica de 120,45 $\mathrm{gg} / \mathrm{La} 137,66 \mu \mathrm{g} / \mathrm{L}$. Não há no Conselho Nacional do Meio Ambiente (Conama) valores comparativos para o ortofosfato.

O principal fator que tem levado o rio Paraíba do Meio a ter índices de poluição, bem como de contaminação, está intimamente ligado a alguns dos problemas de saneamento básico existentes no município de Viçosa. Se houve uma expansão urbana desordenada, consequentemente não se tem saneamento básico, principalmente quando se coloca em questão a existência de moradias nas margens de um rio.

Grande parte das residências localizadas nas proximidades ou margens do rio Paraíba do Meio possuem efluentes domésticos diretamente no leito do rio. $E$ mais, toda estrutura de esgotamento da cidade são conduzidos para o rio sem nenhum tratamento (figura 6).

Devido às alterações ocasionadas pela interferência humana ocorrente das mais variadas formas e intensidades, as quais podem vir a causar de maneira concentrada, através da descarga de efluentes domésticos e industriais, ou de forma difusa a partir do uso de defensivos agrícolas e manejo inadequado do solo. (SPERLING, 2007 apud DANELON; RODRIGUES, 2014, p.96)

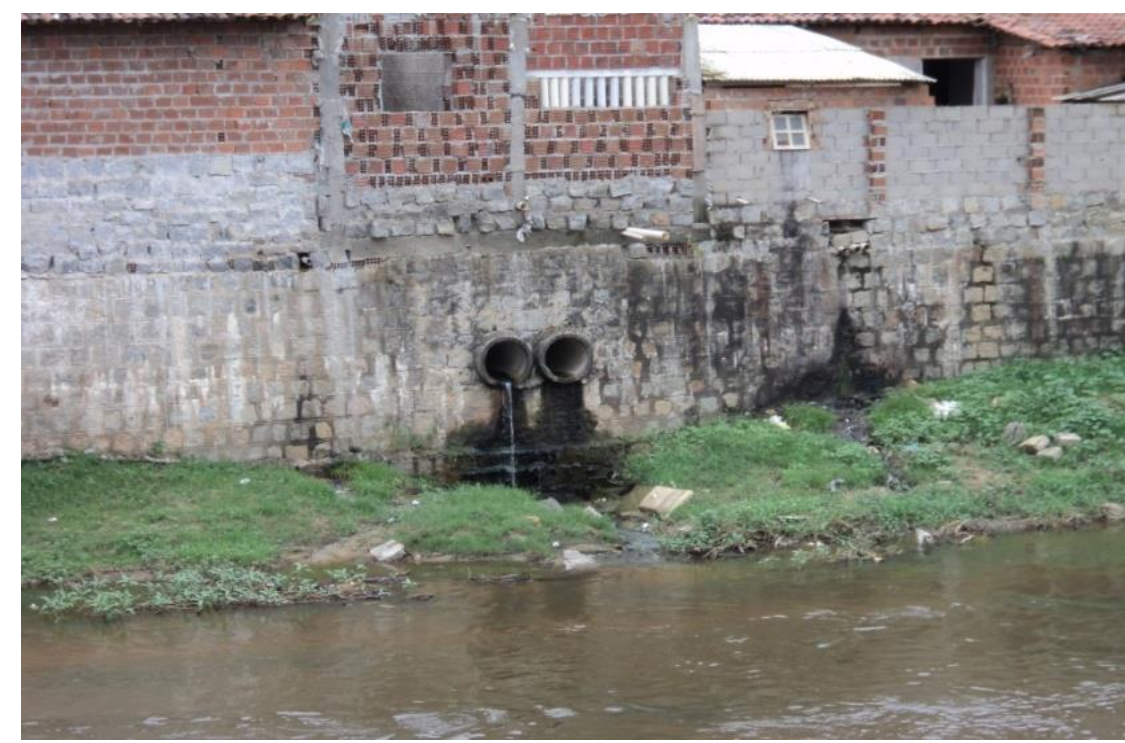

Figura 6: Efluentes domésticos e esgotos direcionados para o leito do rio. Fonte: Acervo dos autores, 2012.

Os moradores também jogam lixo orgânico e inorgânico no rio ou margens. Os orgânicos entram em processo de decomposição e influem muito na contaminação do rio, por exemplo, restos mortais de animais. Os inorgânicos quando não são levados em épocas de enchentes pelas águas do rio, permanecem visivelmente, pois para se decompor demoram anos, tais como plásticos, pneus, dentre outros.

Outro parâmetro analisado em laboratório e que tem relação com a ação humana citada anteriormente refere-se ao fósforo total que, juntamente com o ortofosfato e a amônia, acabam por formar o principal grupo de nutrientes com relação intrínseca com o processo de eutrofização em ecossistemas aquáticos. 
IMPLICAÇÕES SOCIOAMBIENTAIS DO PROCESSO DE APROPRIAÇÃO E USO DO RIO PARAÍBA DO MEIO EM VIÇOŞA (AL)

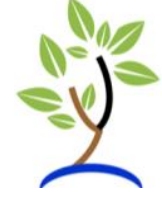

Conforme Esteves (1998):

O fósforo é considerado um importante poluente de cursos de água, principalmente das águas superficiais continentais. Altas concentrações de fósforo na água favorecem o crescimento de algas e plantas que podem vir a interferir na utilização da água para consumo humano ou recreação. (ESTEVES, 1998, p. 81)

Smith e Schindler (2009, p. 61) destacam a eutrofização como "o maior problema da atualidade em corpos de água superficiais, considerando-a como um dos exemplos mais visíveis das alterações ocasionadas pelo homem à biosfera".

O Conama estabelece o valor máximo de fósforo total, $0,1 \mathrm{mg} / \mathrm{L}$ para ambiente lótico e tributários de ambientes intermediários, como é o caso do rio em questão. Os valores obtidos nas coletas das amostras evidenciam que há uma concentração acima do limite estabelecido pelo Conama, pois durante o segundo semestre tem-se uma variação entre os pontos de coleta de $0,13 \mathrm{mg} / \mathrm{l} \mathrm{a} 0,14 \mathrm{mg} / \mathrm{l}$. Noprimeiro semestre essa variação cresce e ocorre a partir de $0,18 \mathrm{mg} / \mathrm{l}$, com máximo de 0,27 mg/l. Desse modo, nota-se concentrações iniciais de fósforo que podem contribuir para um futuro processo de eutrofização em alguns locais do rio em questão.

Os Sólidos Totais Dissolvidos referem-se a um conjunto de todas as substâncias sejam orgânicas ou inorgânicas presentes em um ambiente aquático, sob formas moleculares, inonizadas ou micro-organismos. Constitui mais um importante parâmetro na determinação da qualidade da água.

Foi verificado que o teor de Sólidos Totais Dissolvidos (STD) no rio, durante o segundo semestre, tem uma variação de 173 a 176 mg/l, no primeiro semestre é de 292 a 295 mg/l. Na resolução do Conama no 357, de 17 de março de 2005, Artigo 14, é estabelecido um limite máximo de 500 mg/l. Como ainda está abaixo a água continua acessível para tais fins supracitados, com as devidas restrições. Vale frisar que diante desse panorama, foi verificado em pesquisa de campo que por isso ainda é possível, o uso das suas águas por muitos moradores para lavar roupas e objetos domésticos; bem como crianças tomarem banho.

Nos currais, tem-se também uma contribuição para a contaminação do rio, considerando o fato de serem lançados em suas águas às fezes e urina de animais.

Em se tratando da condutividade elétrica da água, pode-se dizer que a mesma representa a facilidade ou dificuldade de passagem da eletricidade na água. Compostos orgânicos e inorgânicos, por exemplo, contribuem ou interferem na condutividade, de acordo com sua concentração na amostra.

A condutividade elétrica do rio Paraíba do Meio variou no segundo semestre de 266 a $272 \mu \mathrm{S} / \mathrm{cm}$ a $25^{\circ} \mathrm{C}$ e no primeiro semestre de 450 a $455 \mu \mathrm{S} / \mathrm{cm}$ a $25^{\circ} \mathrm{C}$. Neste sentido, há uma variação considerável do primeiro para o segundo semestre. Dentre as atividades humanas que influenciam na condutividade elétrica, são elas: descarga de indústrias, consumo de sais em residência e comércio, excreção de sais pelo homem e animais. Para elucidar essa questão das atividades que influenciam na condutividade elétrica serão socializados os resultados da pesquisa de campo a seguir.

REVISTA GEONORTE, V.9, N.32, p.45-66, 2018.

DOI: 10.21170/geonorte.2018.V.9.N.32.45.66

(ISSN 2237 - 1419) 
Um caso a ser destacado aqui se refere ao Matadouro Público de Viçosa. O mesmo é localizado exatamente nas margens do rio há aproximadamente 40 anos, além de sua instalação contribuir para o desmatamento da mata ciliar, o estabelecimento tem contribuído de maneira significativa durante muito tempo para poluição e contaminação do rio.

Foi verificado que os resíduos sólidos eram lançados nas margens e leito do rio. Toda estrutura do matadouro foi construída com o intuito de despejarem os efluentes no leito do rio (figura 7). No ano de 2011 houve uma inspeção por parte do poder judiciário, mais especificamente a Vara do Trabalho de Palmeira dos Índios, onde o Juiz Federal Dr. Flávio Luiz da Costa, interrompeu as atividades do mesmo. Atualmente o matadouro ainda se encontra inativo e já está em andamento a construção de outro em um novo espaço, dessa feita, afastado do rio.

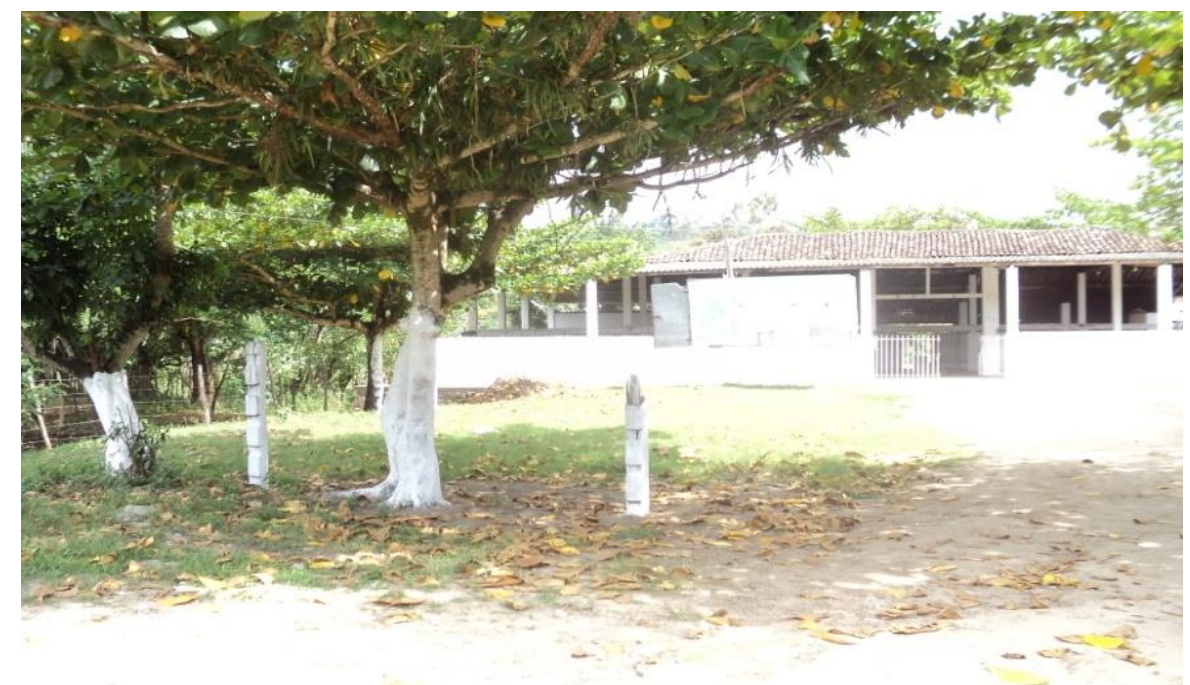

Figura 7: Matadouro público municipal construído às margens do rio. Fonte: Acervo dos autores, 2012.

Existe no matadouro a instalação de um tanque de concreto na planície de inundação do rio para armazenar e separar os resíduos sólidos, ou seja, os restos mortais de animais, no entanto, além de ser em um local inapropriado, não comportando mais os cadáveres, desse modo os mesmos continuam sendo depositados a céu aberto. Frisando também a existência a céu aberto de lixo veterinário e fezes de animais (figura 8). 


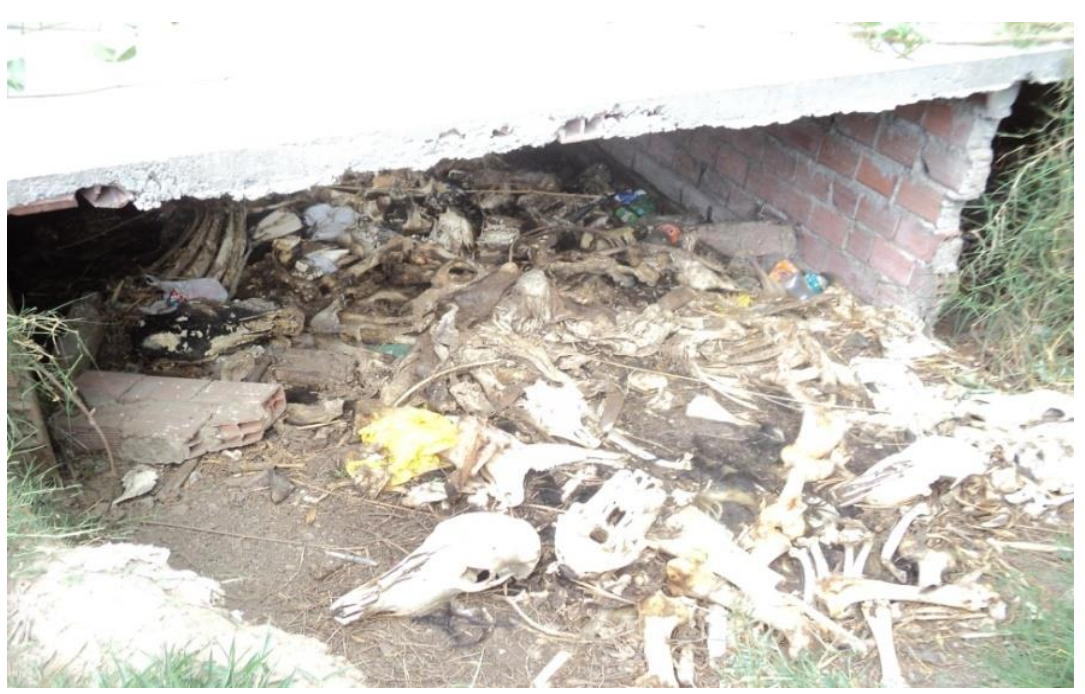

Figura 8: Depósito de restos mortais a céu aberto nas proximidades do matadouro e do rio. Fonte: Acervo dos autores, 2012.

Quanto aos efluentes antes existentes, observou-se que a prefeitura local, responsável pelo funcionamento do matadouro, tentou paliativamente resolver o problema com uma nova estrutura de destino dos dejetos, no entanto, foi constatado que tal ação não foi efetivada, pois a rede de captação de dejetos criada encontra-se sucateada e ainda com alguns efluentes direcionados ao leito do rio.

Outro elemento observado foi nitrogênio, este é um dos elementos mais importantes no metabolismo de ecossistemas aquáticos. Esta importância deve-se principalmente à sua participação na formação de proteínas, um dos componentes básicos da biomassa. Quando presente em baixas concentrações pode atuar como fator limitante na produção primária de ecossistemas aquáticos. (ESTEVES, 1998, p. 96)

Em se tratando de fontes naturais de nitrogênio, tem-se, a saber: a chuva, material orgânico, material inorgânico (de origem alóctone) e a fixação de nitrogênio molecular diretamente no ecossistema aquático. O nitrogênio se faz presente em um ecossistema aquático sob variadas formas, dentre elas tem-se as que forma medidas nesta pesquisa, isto é, Nitrato (NO), Nitrito (NO) e Amônia $\left(\mathrm{NH}_{3}\right)$.

O Nitrogênio (amônio) foi um dos parâmetros analisados. De acordo com o Conama, no 357 , de 17 de março de 2005, em seu Artigo 14, é estabelecido um valor de 3,7 $\mathrm{mg} / \mathrm{L}$ para $\mathrm{pH}$ menor ou igual a 7,5 ; de $2,0 \mathrm{mg} / \mathrm{L}$ para $\mathrm{pH}$ maior que 7,5 e menor ou igual a 8,0 ; de $1,0 \mathrm{mg} / \mathrm{L}$ para $\mathrm{pH}$ maior que 8,0 e menor ou igual a 8,5 ; e de $0,5 \mathrm{mg} / \mathrm{L}$ para $\mathrm{pH}$ maior que 8,5 .

Nos dados obtidos em coleta, o pH do rio Paraíba do Meio é maior que 8,5 e, desse modo, os valores de nitrogênio têm o limite de $0,5 \mathrm{mg} / \mathrm{L}$. Durante o segundo semestre há uma variação de $0,04 \mathrm{mg} / \mathrm{La} 0,12 \mathrm{mg} / \mathrm{L}$. No primeiro semestre a variação é de 0,19 $\mathrm{mg} / \mathrm{La} 0,25 \mathrm{mg} / \mathrm{L}$.

Diante da situação, conclui-se que não há concentração de nitrogênio acima do limite estabelecido pelo Conama, no entanto, os dados indicam que no decorrer do tempo, e se houver continuidade da tipologia de relação entre a população e o rio, sobretudo no que se refere à realidade objetiva das atividades socioeconômicas, pode haver 
agravamento no estágio de poluição e contaminação do rio, inclusive se forem incrementadas mais tipos de atividades (por exemplo, a atividade industrial) que possam impulsionar mais ainda os níveis de contaminação.

Também foi analisada a presença da clorofila a é um dos pigmentos responsáveis pelo processo fotossintético, segundo CETESB (2008) apud Gonçalves (2008, p. 118), a clorofila a "é a mais comum entre as clorofilas e considerada a principal variável indicadora de estado trófico dos ambientes aquáticos".

De acordo com o CONAMA, o tipo de ecossistema aquático como o rio Paraíba do Meio deve ter uma concentração máxima de $10 \mu \mathrm{g} / \mathrm{L}$. Como pode ser observada na tabela 01 , perpassa pelos três pontos de coleta uma variação de clorofila a de $1,5 \mu \mathrm{g} / \mathrm{L}$ a 2,3 $\mu \mathrm{g} / \mathrm{L}$. Desse modo, não se tem um caso indicador de estado trófico.

A temperatura é um fator salutar, pois a mesma acaba por influenciar todos os outros processos físicos, químicos e biológicos de um ambiente aquático. $\mathrm{E}$ mais, tem uma importância no que se refere a interpretação dos demais processos que ocorrem na água.

Para Gonçalves (2008, p. 37) o aumento da temperatura aquática, que se situa entre $0^{\circ}$ e $25^{\circ}$ provoca diminuição na viscosidade e densidade acima de $4^{\circ} \mathrm{C}$. Desse modo, facilita a sedimentação de materiais em suspensão, aumentam a transferência de gazes entre água e atmosfera e diminuem a solubilidade de gases na água.

Levando em consideração as proposições de Gonçalves e os dados de coleta obtidos, foi verificada a seguinte situação: durante o segundo semestre a temperatura varia de $26,67^{\circ} \mathrm{C}$ a $27,39^{\circ} \mathrm{C}$. Durante o primeiro semestre varia de $26^{\circ} \mathrm{C}$ a $26,33^{\circ} \mathrm{C}$. Como se verificou um leve, mas, considerável aumento de temperatura que ultrapassa os $25^{\circ} \mathrm{C}$ buscou-se em pesquisa de campo conhecer, por exemplo, a atividade de pesca no rio. Segundo moradores locais, muitos viviam da pesca, mas hoje isso já não é mais possível, pois houve uma diminuição de peixes no rio. Desse modo, conclui-se que o efeito físico-químico dessa elevação de temperatura provocou aumento da concentração do amoníaco livre e tóxico para peixes $\left(\mathrm{NH}_{3}\right)$.

Oxigênio Dissolvido foi outro parâmetro analisado e que possui importante participação no contexto aqui discutido. Ele é um elemento de vital importância para os seres aquáticos aeróbicos. De acordo com Von Sperlling (2005) apud Gonçalves (2008, p.66) o Oxigênio Dissolvido é o principal parâmetro de caracterização dos efeitos da poluição das águas por despejos orgânicos. Em torno de $4-5 \mathrm{mg} / \mathrm{L}^{-1}$ morrem todos os peixes; igual a $2 \mathrm{mg} / \mathrm{L}^{-1}$ todos os peixes estão mortos e igual a 0 $\mathrm{mg} / \mathrm{L}^{-1}$ apresenta condições de anaerobiose. Para Carmouze (1994) apud Gonçalves (2008, p. 67) em condições normais um rio considerado limpo, apresenta normalmente, de 8 a $10 \mathrm{mg} / \mathrm{L}^{-1}$.

O rio Paraíba do Meio apresenta uma variação de OD durante o segundo semestre de $6,74 \mathrm{mg} / \mathrm{L}$ a $7,2 \mathrm{mg} / \mathrm{L}$. Durante o primeiro semestre varia de $6,96 \mathrm{mg} / \mathrm{L}$ a 7,6 $\mathrm{mg} / \mathrm{L}$.Desse modo, levando em consideração o que Carmouze fala o rio supracitado apresenta um quadro de poluição. Em pesquisa de campo foi observado a presença de lixos orgânicos e inorgânicos introduzidos no rio pela população e não há uma fiscalização por parte do poder público competente (figura 9). 


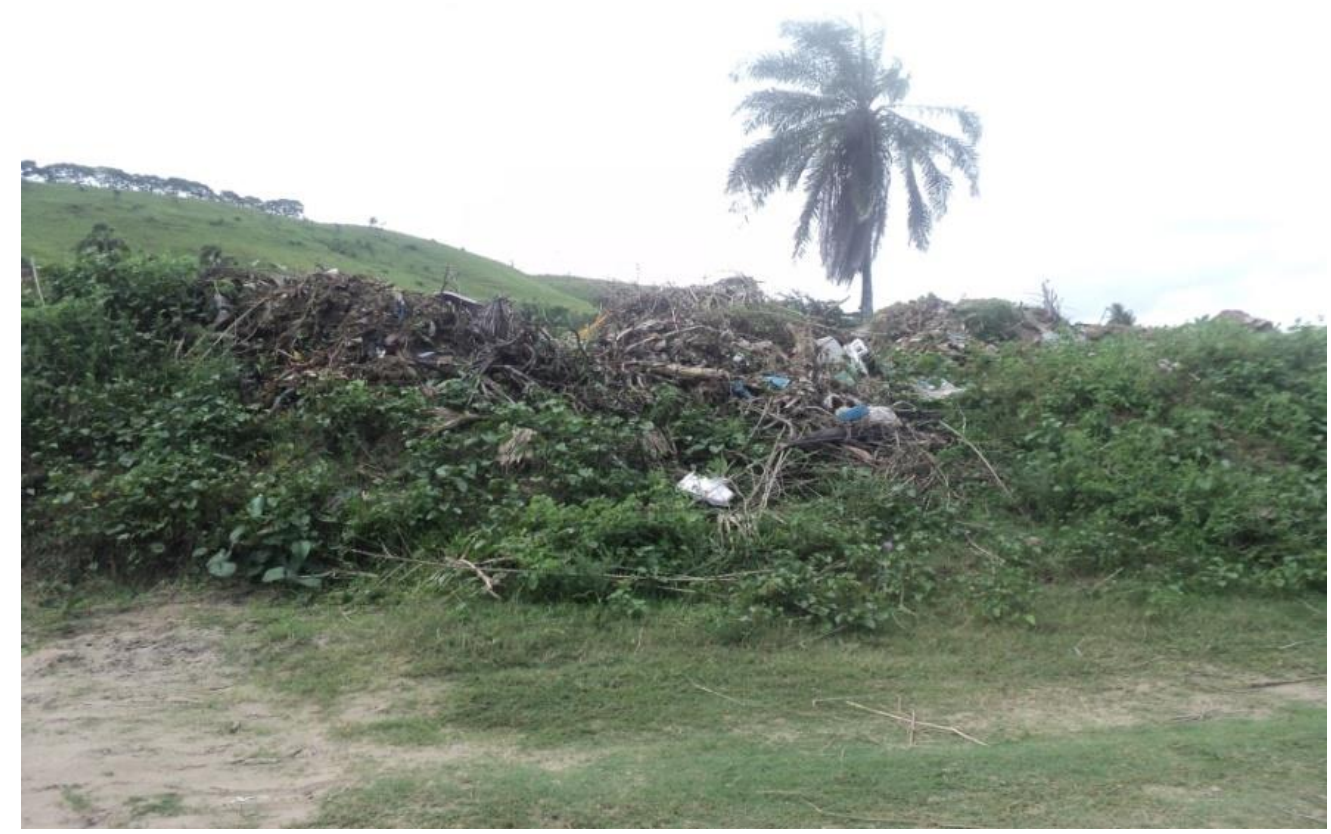

Figura 9: Depósito de lixo nas margens do rio.

Fonte: Acervo dos autores, 2012.

\section{ALTERAÇÕES FÍSICAS}

Aqui se têm dois problemas ambientais principais: o assoreamento e a dragagem dos bancos de areia. O rio Paraíba do Meio é de regime pluvial e, desse modo, principalmente no período pós-inverno é comum o surgimento de bancos de areia ao longo do leito do rio, ou seja, o mesmo fica assoreado. Tal fenômeno acontece devido à baixa na quantidade de água e desse modo não há energia suficiente para transportar os aluviões do rio.

Deve-se considerar que a erosão provocada pela retirada da mata ciliar induziu o aparecimento ao longo do leito do rio de bancos de areia, indicando o assoreamento que o mesmo está submetido. Essa degradação tornou ao longo dos anos o rio impróprio para navegação de pequenos barcos, o que em outrora já foi possível, segundo relatos dos moradores.

Há o aproveitamento econômico dos bancos de areia que vão se formando ao longo do leito do rio para construção civil. Para tanto, é realizado o processo de dragagem no rio, mas esta atividade ocorre sem fiscalização ou supervisão técnica. Esta é realizada de maneira aleatória (figura 10). 


\section{Uy REVISTA GEONORTE}

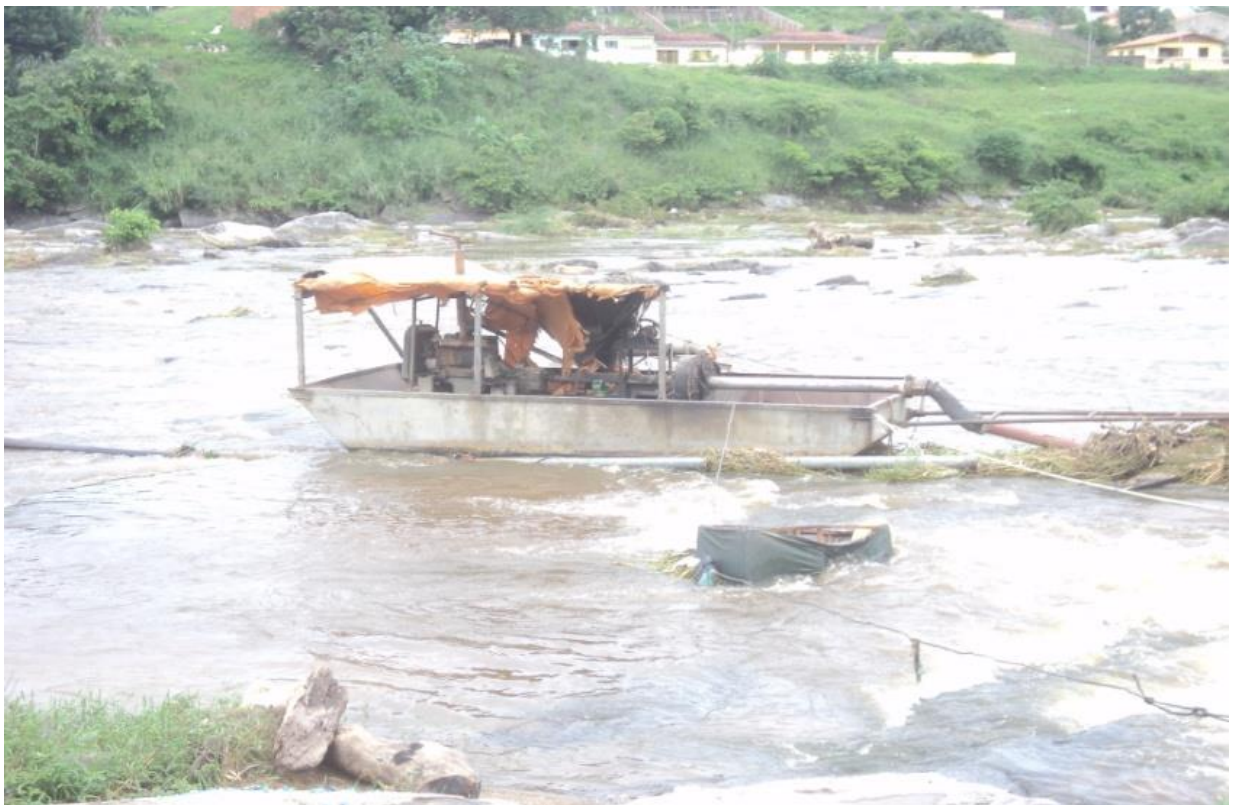

Figura 10: Máquina de dragagem em operação montada pelos próprios trabalhadores. Fonte: Acervo dos autores, 2012.

Como muitos moradores têm essa atividade como uma complementação de sua renda, a dragagem não se restringe apenas aos bancos de areia, estendendo-se para outros pontos do rio (figura 11). Dessa forma, retirada inapropriada dos sedimentos acaba por provocar uma alteração no regime natural de concentração de nutrientes e sedimentos que, por sua vez, influi no Complexo Lagunar Mundaú-Manguaba em Alagoas.

Observou-se ainda as diversas formas de contaminação da água, em geral estão relacionadas ao uso e ocupação do solo, cuja contaminação dos sedimentos muitas vezes pode estar diretamente ligada à contaminação da água. $O$ resultado dessas alterações representa uma queda acentuada da biodiversidade aquática, em função da desestruturação do ambiente físico, químico e alterações na dinâmica e estrutura das comunidades biológicas. (CALLISTO et al., 2001 apud MENDES; RIBEIRO, 2014, p. 122). 


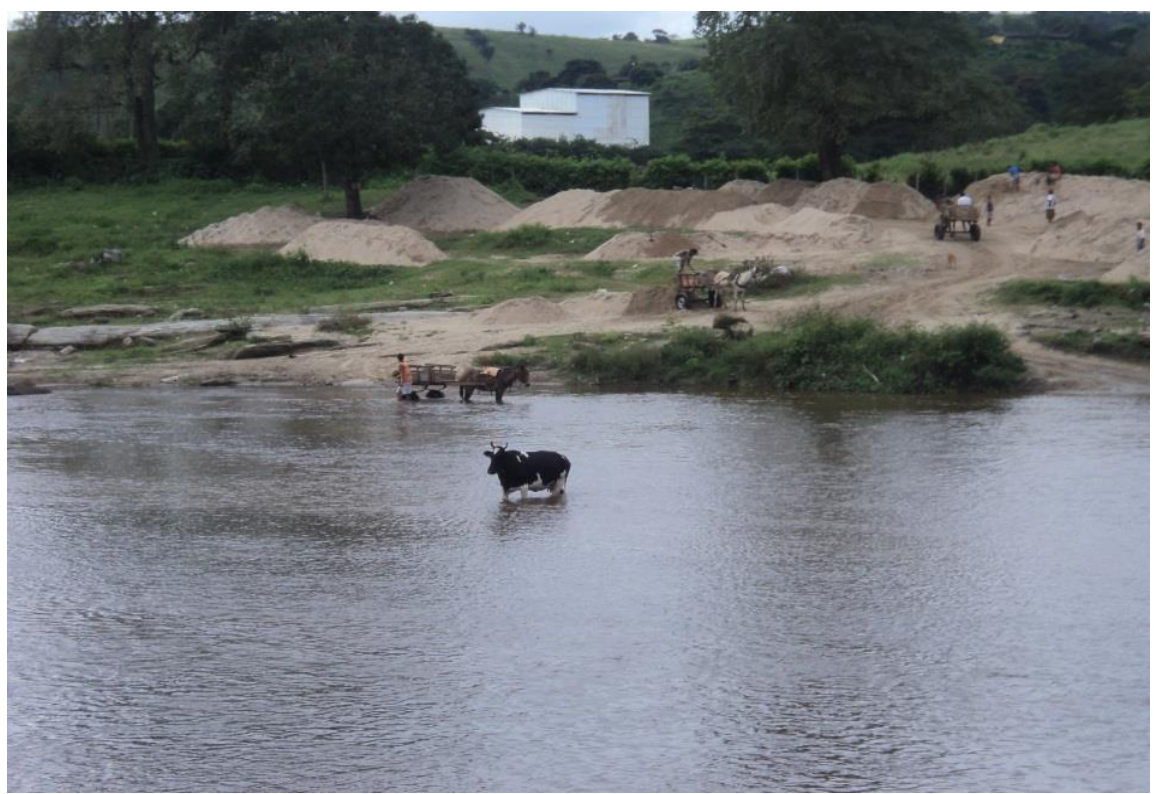

Figura 11: Dragagem no rio Paraíba do Meio.

Fonte: Acervo dos autores, 2012.

\section{ALTERAÇÕES NA VEGETAÇÃO E OCUPAÇÃO IRREGULAR}

A expansão urbana provocou o desmatamento da mata ciliar que, por sua vez, traz em sua esteira outros problemas. Assim como muitas cidades no mundo, Viçosa também cresceu tendo o rio como seu marco zero. Sabe-se que com o desenvolvimento da cidade, ocorre o crescimento populacional, assim como a demanda por moradia, sendo assim, o relevo é de grande importância para a expansão dessa malha urbana, por isso deve ser levado em consideração quando ocupado. (PEDRO e SANTOS, 2014, p. 82)

A grande problemática em relação a isso se deve ao fato de que, principalmente no Brasil, essa expansão ocorreu de maneira desordenada e sem planejamento. $O$ resultado é ocupação irregular na planície de inundação do rio e o consequente desmatamento da mata ciliar (figura 12). 


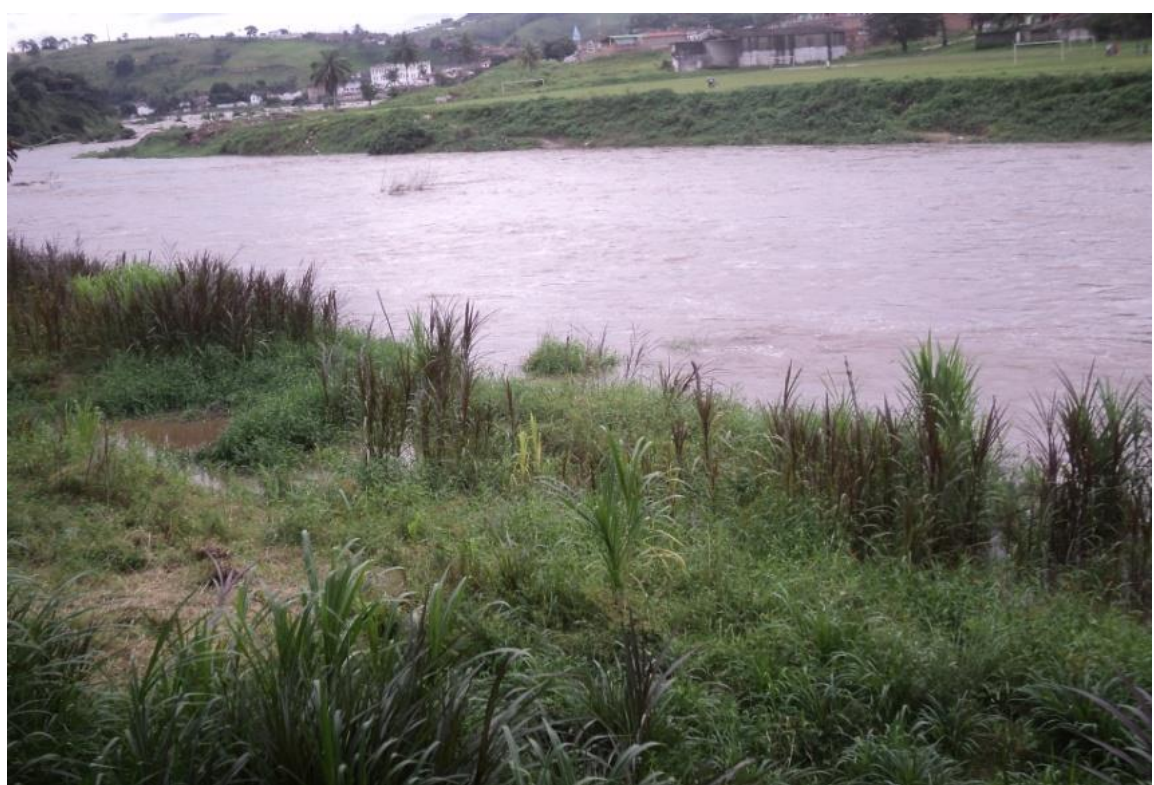

Figura 12: Vertentes do rio sem mata ciliar devido alteração antrópica.

Fonte: Acervo dos autores, 2012.

Denominam-se matas ciliares, as formações vegetais encontradas ao longo de cursos d'água que têm como função principal a proteção da água, evitando o processo de erosão das margens e o assoreamento do leito dos cursos e corpos d'água. Essa vegetação influencia diretamente na qualidade da água e na manutenção do ciclo hidrológico nas bacias hidrográficas. Também, atuam como habitats naturais para diversas espécies de animais, favorecendo o fluxo gênico e aumentando a diversidade genética nas populações (BRAC KMANN e FREITAS, 2013 apud MORAIS e SAIS, 2016, p. 72).

A presença de matas ciliares é de extrema importância para, além da manutenção do equilíbrio natural (ciclo hidrológico, diversidade de espécies, evitar o assoreamento dos corpos d'água, etc.), ajuda na preservação da qualidade hídrica diretamente, servindo como barreira para materiais provenientes de lixiviação. (MORAIS e SAIS, 2016, p. 34).

A vegetação das margens de rios é considerada uma APP, desse modo o Código Florestal de 2012 determina os seguintes valores, ver quadro 1:

Quadro 1: Dimensões das áreas de mata ciliar de acordo com a largura e natureza dos corpos d'água.

\begin{tabular}{|l|l|}
\hline SITUAÇÃO & LARGURA MíNIMA DA FAIXA \\
\hline Cursos d'água com menos de 10m de largura & $30 \mathrm{~m}$ em cada margem ao longo do curso \\
\hline Cursos d'água com largura entre $10 \mathrm{~m}$ e $50 \mathrm{~m}$ & $50 \mathrm{~m}$ em cada margem ao longo do curso \\
\hline Cursos d'água com largura entre $50 \mathrm{~m}$ e $200 \mathrm{~m}$ & $100 \mathrm{~m}$ em cada margem ao longo do curso \\
\hline Cursos d'água com largura entre $200 \mathrm{~m}$ e $600 \mathrm{~m}$ & $200 \mathrm{~m}$ em cada margem ao longo do curso \\
\hline Cursos d'água com largura superior a $600 \mathrm{~m}$ & $500 \mathrm{~m}$ em cada margem ao longo do curso \\
\hline $\begin{array}{l}\text { Áreas no entorno de lagos e lagoas naturais com } \\
\text { área de superfície de até } 20 \text { hectares }\end{array}$ & Largura mínima $50 \mathrm{~m}$ de faixa marginal \\
\hline $\begin{array}{l}\text { Áreas no entorno de lagos e lagoas naturais com } \\
\text { área de superfície acima de } 20 \text { hectares }\end{array}$ & $\begin{array}{l}\text { Largura mínima de 100m para zona rural e 30m } \\
\text { para zona urbana }\end{array}$ \\
\hline $\begin{array}{l}\text { Áreas em torno de nascentes e olhos d'água } \\
\text { perenes }\end{array}$ & Raio mínimo de $50 \mathrm{~m}$. \\
\hline
\end{tabular}

Fonte: Adaptado de: Lei 12.651, de 25 de maio de 2012.

REVISTA GEONORTE, V.9, N.32, p.45-66, 2018.

DOI: 10.21170/geonorte.2018.V.9.N.32.45.66

(ISSN 2237 - 1419) 
Foi evidenciado em estudo de campo que a existência de atividades agrícolas baseada na produção mercantil simples (figura 13). São famílias que dependem dessa atividade como principal fonte de renda familiar, desenvolvendo o plantio de culturas tais como: macaxeira, batata, cana-de-açúcar, alface, coentro, milho, feijão, etc. voltados para o autoconsumo, com o excedente encaminhado para a feita livre de Viçosa-Alagoas; há ainda a prática de uma pecuária simples.

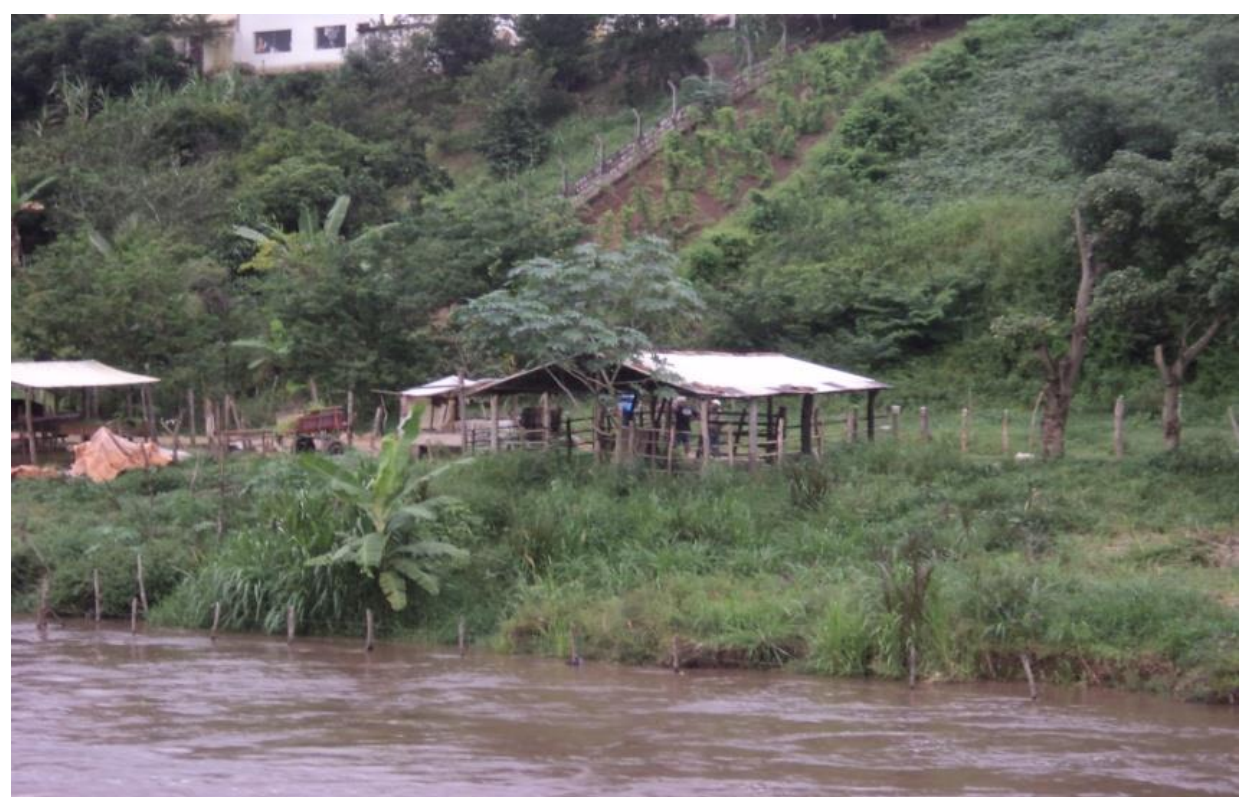

Figura 13: Instalação de currais para criação de animais e pequenos plantios de culturas na vertente direita do rio. Fonte: Acervo dos autores, 2012.

A preferência de alguns agricultores pela planície aluvial do rio está associada a dois fatores: o fato de ser uma área de considerável fertilidade, pois o rio deposita aluviões autóctones e alóctones vindos em suspensão que, proporcionam ao solo grande fertilidade.

Além da ocupação indevida dessas margens para instalação de currais e plantios, tem-se também a construção de habitações. Muitas ruas de Viçosa, inclusive entre as principais, são localizadas às margens do rio e isso tem levado muitos habitantes sofrerem no período de enchentes. A última foi em 2010 que o rio vitimou muitos alagoanos que moram nas proximidades do rio.

Desse modo, pensa-se que há lugares no território municipal que podem ser ocupados, óbvio que de maneira planejada, para realocação da população ribeirinha. Contudo, isso não é colocado em prática. Daí advém à questão do direito a cidade. Segundo Carlos (2013, p. 108) apud Frota e Oliveira (2017, p. 06) "[...] é possível entender o "direito a cidade" como uma necessidade prática de superação da contradição valor de uso-valor de troca, que só se resolveria na superação daquilo que funda o capitalismo: a propriedade privada".

O Plano Diretor (2006) de Viçosa - Alagoas contempla uma mudança nesse quadro de ocupações ribeirinhas indevidas, mas foi verificado que até o momento não houve aplicabilidade deste importante instrumento de política e planejamento urbano. 
IMPLICAÇÕES SOCIOAMBIENTAIS DO PROCESSO DE APROPRIAÇÃO E USO DO RIO PARAÍBA DO MEIO EM VIÇOŞA (AL)

\section{渷}

\section{CONCLUSÃO}

A necessidade social de apropriação e uso do rio é incontestável, pois faz parte do suprimento da satisfação do que a sociedade precisa para crescer e se desenvolver economicamente. No entanto, ficou aqui provado que o atual modelo de apropriação não vem trazendo implicações positivas tanto para o rio, como para o homem que precisa dele.

É fundamental ter noção de que a partir do momento em que o homem, por meio do trabalho, passa a ter os instrumentos necessários que o possibilitam deixar de ser nômade, ele dar um salto extremamente importante em seu desenvolvimento: a descoberta da agricultura. Agora ele passa a ter domínio da natureza. Ao longo do tempo ele foi capaz de aperfeiçoar seus instrumentos de trabalho e suas técnicas com a finalidade de satisfizer suas necessidades, porém deve se aperfeiçoar também medidas mitigadoras que busquem um equilíbrio na apropriação e no uso dos recursos hídricos.

Os problemas ambientais aqui elencados e discutidos evidenciam a negatividade no que se refere ao resultado da relação da sociedade de Viçosa - Alagoas com o Rio Paraíba do Meio. É importante que pesquisas como essa venham a público para o conhecimento da sociedade e, sobretudo, das autoridades competentes para que se (re) pense o atual modelo de apropriação e uso dos recursos naturais como um todo. E mais, que a legislação vigente tenha aplicabilidade prática para nortear e mediar à relação supracitada.

\section{REFERÊNCIAS}

AGÊNCIA NACIONAL DAS ÁGUAS - ANA. [online]. Brasília: ANA, 2012. Acessado em: 16 Julho 2012.

BRASIL. Resolução no 357 de 17 de Março de 2005. Alterada pela Resolução 410/2009 e pela 430/2011. Conselho Nacional do Meio Ambiente - CONAMA. Brasília, DF, 2005.

CASSETI, Valter. Ambiente e apropriação do relevo. São Paulo: Contexto. 1991.

DANELON, J. R. B.; RODRIGUES, S. C. Análise dos níveis de turbidez na bacia hidrográfica do Córrego do Glória, Uberlândia/MG. Revista Geonorte, Manaus, Edição Especial 4, v. 10, N. 1, p. 123-126, 2014.

ESTEVES, F. A. Fundamentos de Limnologia. 2. ed. Rio de Janeiro: Editora Interciência, 1998.

FROTA, Arlan, Justino; OLIVEIRA, Jose Aldemir de. A construção de moradias flutuantes e o direito a cidade em Tapauá-AM. Revista Geonorte, Manaus, v. 08, n. 28, p. 01/15, 2017. 
GUERRA, A. T.; GUERRA, A. J. T. Novo dicionário geológico-geomorfológico. 8. ed. Rio de Janeiro: Bertrand Brasil, 2010.

GONÇALVES, G. W. P. S. Urbanização e qualidade da água: monitoramento em lagos urbanos de Londrina - PR. Dissertação de mestrado. Universidade Estadual de Londrina, Centro de Ciências Exatas, Programa de Pós-Graduação em Geografia, Meio Ambiente e Desenvolvimento. Londrina, 2008.

MENDONÇA FILHO. História Econômica. São Paulo: Perspectiva 1977.

MENDES, I. A. S.; RIBEIRO, E. V. A qualidade da água e do sedimento na bacia do córrego Tripuí, Ouro Preto - MG: ensaios de ecotoxidade e uso do solo. Revista Geonorte, Manaus, Edição Especial 4, v. 10, N. 1, p. 46-51, 2014.

MINISTÉRIO DE MINAS E ENERGIA. Projeto de cadastro de fontes de abastecimento por água subterrânea - Diagnóstico do Município de Viçosa. Recife, 2005.

MORAIS, R. S.; SAIS, A. C. Caracterização e diagnóstico ambiental das áreas de preservação permanente da calha principal do manancial de abastecimento da cidade de Teófilo Otoni, MG. Revista Geonorte, Manaus, v. 7, n. 27, p. 1-17, 2016.

PEDRO, L.; SANTOS, W. A. Análise dos impactos ambientais causados pelas construções urbanas nas vertentes do córrego São José, localizado nos bairros Canaã 1 e 2, situados no município de Ituiutaba - MG. Revista Geonorte, Manaus, Edição Especial 4, V. 10, N. 1, p. 118-122, 2014.

SANTOS, M. Pensando o espaço do homem. São Paulo: Edusp, 2004.

SMITH, V. H.; SCHINDLER, D. W. Eutrophication science: where do we go from here?.Trends in Ecology and Evolution 24: 201-207. 2009.

SPANGHERO, P. E. S. F.; MOREAU, M. S.; MACEDO, S. M. Bacias hidrográficas urbanas: qualidade da água e conflitos ambientais na cidade de Ilhéus - BA. Revista Geonorte, Manaus, v. 8, N.29, p. 134-152, 2017.

Submetido em: 24/04/2018 Aceito para publicação em: 04/06/2018 